\title{
Rancang Bangun Spectrum Analyzer Menggunakan Fast Fourier Transform Pada Single Board Computer
}

\author{
Afandi Nur Aziz Thohari*1, Agfianto Eko Putro², \\ ${ }^{1}$ Program Studi S2/S3 Ilmu Komputer, FMIPA UGM, Yogyakarta \\ ${ }^{2}$ Jurusan Ilmu Komputer dan Elektronika, FMIPA UGM, Yogyakarta \\ e-mail: *1.
}

\begin{abstract}
Abstrak
Spectrum analyzer merupakan alat yang berfungsi untuk mengubah sinyal dalam ranah waktu menjadi spektrum dalam ranah frekuensi. Sebuah alat penganalisa sinyal umumnya memiliki ukuran yang besar sebab terdiri dari banyak komponen seperti mixer, amplifier, local osilator, ADC dll. Selain ukuran, masalah dari spectrum analyzer yang ada di pasaran adalah tingginya utilitas yang disebabkan oleh banyaknya titik cuplikan dari sinyal. Utilitas yang tinggi mengakibatkan spektrum yang ditampilkan menjadi lambat.

Oleh sebab itu, dalam penelitian ini dirancang purwarupa spectrum analyzer berukuran kecil menggunakan single board computer, RTL-SDR dan LCD touchscreen. Fungsi spectrum analyzer diimplementasikan dalam sebuah perangkat lunak dengan menerapkan algoritma fast fourier transform. Masukan yang diproses berupa sinyal radio yang dicuplik dalam beberapa titik untuk mengetahui utilitas dari SBC.

Kesimpulan yang diperoleh dari hasil pengujian yaitu utilitas SBC dapat menampilkan spektrum dengan normal pada jumlah cuplikan (N) dari 512 sampai 32.768 titik. Sebab penggunaan $N$ lebih dari 32.768 titik akan membebani cpu dan memori sehingga spektrum yang ditampilkan menjadi lambat. Kemudian jangkauan frekuensi yang dapat ditampilkan purwarupa oleh adalah $24 \mathrm{MHz}$ sampai $1.769 \mathrm{MHz}$. Purwarupa dapat menunjukan letak spektrum radio secara tepat setelah dilakukan perbandingan level spektrum menggunakan spectrum analyzer Anritsu MS2720T.
\end{abstract}

Kata kunci-Sinyal Radio, Cuplikan, Utilitas, level spektrum

\begin{abstract}
Spectrum analyser is device that function to change signal in time domain to spectrum to frequency domain. An analyzer signal device normally have big size cause consist so many component such as mixer, amplifier, local osilator and ADC etc. Beside of size, the problem of spectrum analyzer which on market is high utilities that caused by so many sample from signal. High utilities causing spectrum that displayed become slow.

Therefore, in this research designed spectrum analyser prototype with small size using single board computer, RTL-SDR, and LCD touchscreen. Function of spectrum analyser implemented on a software with applying fast fourier transform algoritm. Input that processed is radio signal which sampled into some point to find out SBC utilities.

Conclusions that obtained from testing result that are SBC utilities can showing normal spectrum on sampling number (N) from 512 until 32.768 points. Because $N$ utilization more than 32.768 point will burden cpu and memory so that spectrum are shown become slow. Then frequency range that could prototype shown is $24 \mathrm{MHz}$ until $1.769 \mathrm{MHz}$. Prototype can showing position radio spectrum appropriately after did comparision spectrum lever using spectrum analyser Anritsu MS2720T.
\end{abstract}

Keywords - Radio Signal, Sampling, Utilities, Spectrum Level 


\section{PENDAHULUAN}

Derkembangan teknologi khususnya dalam bidang elektronika mengalami perkembangan yang cukup pesat. Salah satu diantaranya dibidang pengolahan sinyal digital. Dalam teori pengolahan sinyal digital terdapat sub bidang yang membahas analisis spektrum frekuensi atau disebut spectrum analyzer. Piranti ukur spectrum analyzer berfungsi untuk mengukur besarnya frekuensi dan daya suatu sinyal[1].

Kebutuhan spectrum analyzer di Indonesia sangat banyak, utamanya bagi telekomunikasi dan pendidikan[2]. Dalam bidang telekomunikasi, piranti ukur digital ini dimanfaatkan untuk melakukan pengujian pada alat telekomunikasi saat proses produksi dan perawatan. Kemudian digunakan pula untuk mengetahui alokasi frekuensi yang belum dipakai. Sedang dalam bidang pendidikan spectrum analyzer banyak dipakai di laboraturium fisika dan elektronika untuk praktikum analisa sinyal digital.

Spectrum analyzer yang ada di pasaran, umumnya memiliki ukuran yang besar sehingga tidak mudah dibawa kemana-mana (portable). Hal ini dikarenakan banyak komponenkomponen penyusun spectrum analyzer seperti mixer, amplifier, local osilator, ADC dll. Selain itu juga jangkauan frekuensi yang dapat ditampilkan hanya berkisar antara HF (High Frequency) sampai VHF (Very High Frequency) dengan utilitas sistem yang besar.

Salah satu alternatif untuk mengatasi masalah tersebut, dirancanglah sebuah purwarupa spectrum analyzer yang terdiri dari beberapa perangkat seperti single board computer, RTLSDR dan LCD touchscreen. Sedangkan untuk fungsi spectrum analyzer diimplemetasikan dalam sebuah perangkat lunak. Dalam perangkat lunak diterapkan algortima fast fourier transform yang digunakan untuk mengubah sinyal menjadi spektrum secara cepat dan efisien[3].

\subsection{Analisis Sistem}

\section{METODE PENELITIAN}

Sistem yang dibangun pada penelitian ini adalah sebuah purwarupa alat yang dapat melakukan fungsi kerja seperti spectrum analyzer. Masukan dari purwarupa spectrum analyzer ini adalah sinyal radio, dan keluarannya berupa spektrum frekuensi. Perancangan purwarupa meliputi perancangan perangkat keras dan perancangan perangkat lunak. Perancangan perangkat keras dilakukan dengan cara mengintegrasikan Single Board Computer, RTL-SDR dan LCD touchscreen melalui port yang tersedia. Sedangkan perancangan perangkat lunak dilakukan dengan membuat program yang mengimplementasikan algortima FFT untuk mengubah sinyal menjadi spektrum.

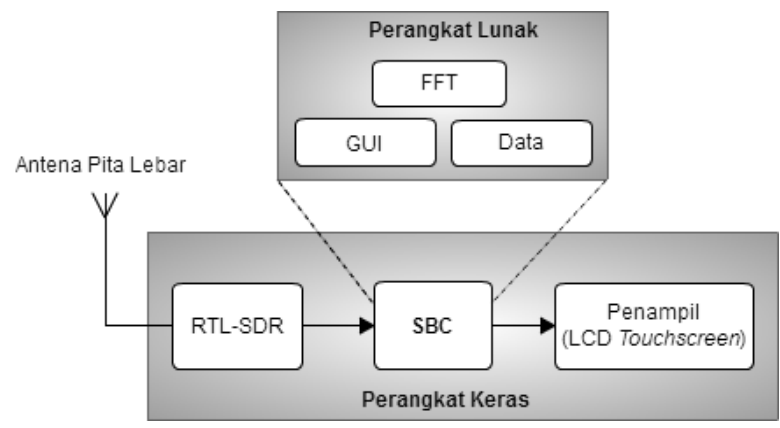

Gambar 1 Diagram Blok Sistem

Gambar 1 menunjukkan diagram blok rancangan sistem keseluruhan yang menggambarkan komponen perangkat keras dan perangkat lunak. Penjelasan bagian-bagian dari diagram blok Gambar 1 adalah sebagai berikut :

1. Antena Pita Lebar

Perangkat yang digunakan untuk menerima gelombang radio yang dipancarkan oleh berbagai stasiun pemancar. 
2. RTL-SDR

Perangkat yang digunakan untuk mengolah sinyal mentah yang diterima antena.

3. $\quad$ SBC (Single Board Computer)

Perangkat yang digunakan untuk melakukan pemrosesan sinyal menjadi spektrum.

Komponen perangkat lunak yang akan diimplementasikan pada SBC terdiri dari :

a. Data

Data yang akan diolah menjadi spektrum adalah data sinyal digital. Data ini di peroleh dari RTL-SDR setelah melakukan pengolahan sinyal radio analog.

b. FFT (Fast Fourier Transform)

Merupakan suatu metode yang digunakan untuk mengubah sinyal menjadi spektrum. Metode FFT terdiri dari beberapa proses yaitu melakukan pembalikan bit, menentukan twiddle factor, dan perhitungan dengan diagram kupu-kupu.

c. GUI (Graphical User Interface)

Tampilan perangkat lunak yang terdiri dari tampilan spektrum dan menu program.

\section{LCD Touchscreen}

Perangkat yang digunakan untuk menampilkan menu program dan visualisasi spektrum yang dihasilkan.

Perancangan sistem pada Gambar 1 menjelaskan bahwa antar perangkat saling terintegrasi melalui port yang tersedia. Setelah semua perangkat terhubung dan dapat melakukan fungsi kerjanya, langkah selanjutnya adalah membuat perangkat lunak spectrum analyzer. Perangkat lunak dibuat dengan menerapkan algoritma FFT, data yang diolah adalah sinyal digital, dan tampilannya dalam bentuk GUI.

SBC yang digunakan untuk mengimplementasikan sistem adalah Raspberry Pi. Digunakan Raspberry Pi sebab memiliki pin GPIO yang dapat dihubungkan dengan perangkat eksternal lain seperti LCD. Selain itu Raspberry Pi juga mempunyai port USB yang pada penelitian ini digunakan untuk berkomunikasi dengan RTL-SDR. Raspberry pi memiliki 40 pin yang terdiri dari 28 pin GPIO, 4 pin power (baik 3,3V maupun 5V), dan 8 pin ground. Namun dari 40 pin SBC, hanya 26 pin saja yang digunakan untuk terhubung dengan LCD.

Selain pin konektor, SBC juga memiliki port USB yang nantinya terhubung dengan RTLSDR. Perangkat penerima sinyal radio ini mengubah sinyal analog radio menjadi sinyal digital lalu mengalirkannya ke SBC. Komponen yang terdapat pada RTL-SDR terdiri dari port RF yang terhubung ke antena, lalu tuner yang berfungsi mencari sinyal RF, terakhir ADC (Analog digital Converter) yang berfungsi mengubah sinyal analog menjadi digital. Agar lebih jelas mengenai komponen yang terdapat pada RTL-SDR, maka dapat dilihat diagram konseptual pada Gambar 2.

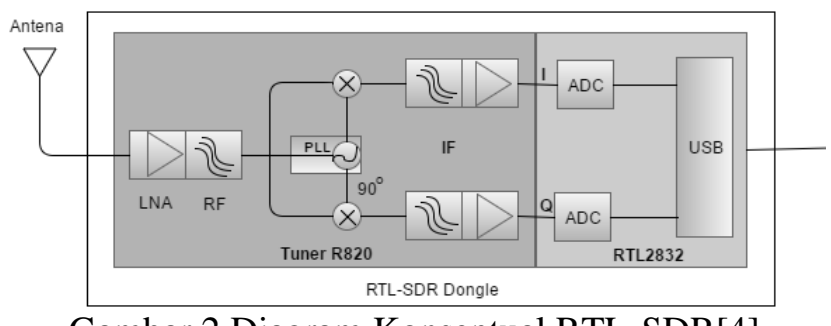

Gambar 2 Diagram Konseptual RTL-SDR[4]

Setelah semua perangkat keras terhubung dan dapat melakukan fungsi kerjanya, maka langkah selanjutnya adalah melakukan perancangan perangkat lunak. Proses perancangan perangkat lunak terdiri dari perancangan visualisasi spektrum, perancangan algoritma FFT, dan perancangan antarmuka pengguna. Perancangan visualisasi spektrum frekuensi ditunjukkan pada Gambar 3. 


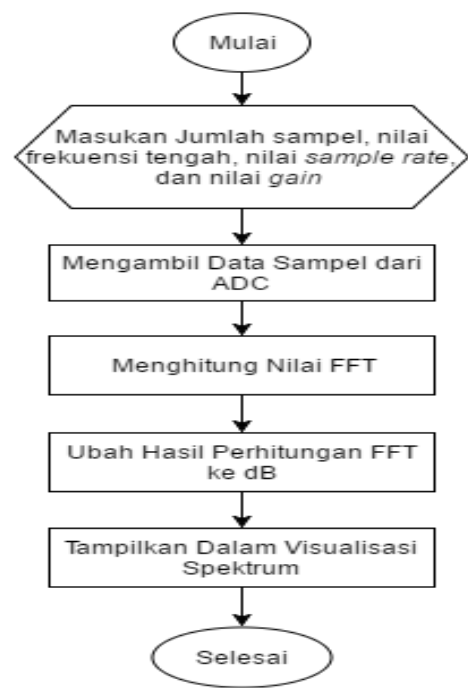

Gambar 3 Diagram Alir Proses Visualisasi Spektrum

Pada Gambar 3 terdapat beberapa langkah yang dilakukan. Program diawali dengan inisialisasi variabel yang digunakan seperti jumlah sampel, nilai frekuensi tengah, dll. Kemudian data sampel yang sudah didapatkan diproses menggunakan FFT dan hasilnya diubah dalam bentuk $\mathrm{dBm}$. Terakhir hasil dalam $\mathrm{dBm}$ ditampilkan dalam bentuk spektum frekuensi.

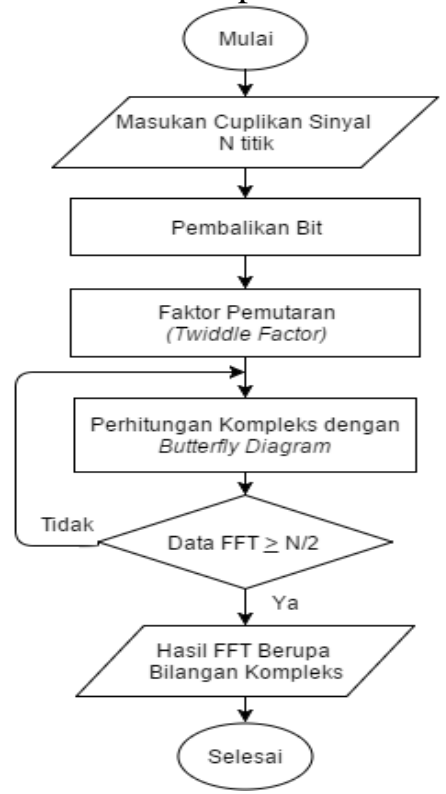

Gambar 4 Diagram Alir Komputasi FFT DIT

Gambar 4 menunjukkan diagram alir dari proses komputasi FFT DIT. Masukan berupa sinyal digital yang dicuplik sebanyak $\mathrm{N}$ titik. Setelah jumlah sampel sebanyak $\mathrm{N}$ titik didapatkan, langkah selanjutnya adalah merangkai nilai dari sampel tersebut dengan pembalik bit. Hasil dari proses pembalik bit adalah pengelompokan titik sesuai bilangan genap dan ganjil. Setelah dipisah dalam genap dan ganjil, langkah selanjutnya adalah menentukan nilai faktor pemutar (twiddle factor). Besarnya faktor pemutar ditentukan dengan persamaan berikut.

$$
W_{N}^{k}=e^{\frac{-j 2 \pi k}{N}}
$$

Nilai faktor pemutar yang telah didapatkan menggunakan persamaan (1), kemudian dihitung menggunakan metode kupu-kupu. Hasil dari proses perhitungan dengan metode kupukupu akan membagi data menjadi separuh dari jumlah cuplikan[5]. Apabila jumlah data belum memenuhi N/2 maka akan dihitung kembali dengan metode kupu-kupu. 


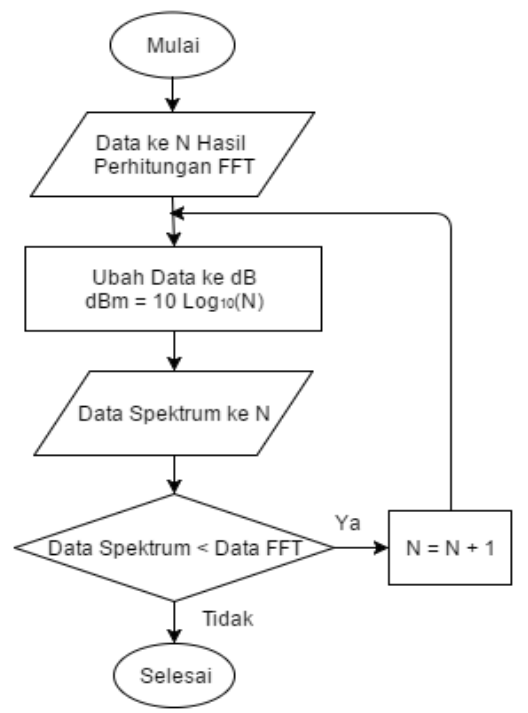

Gambar 5 Diagram Alir Konversi ke dBm

Gambar 5 menunjukkan proses konversi nilai hasil FFT menjadi bentuk dBm. Hasil perthitungan FFT adalah berupa bilangan kompleks, sehingga belum bisa digunakan untuk menggambarkan level spektrum. Proses mengubahan bilangan kompleks menjadi $\mathrm{dBm}$ ditunjukkan pada persamaan (2), dimana $\mathrm{dBm}$ adalah menunjukkan tingkatan sinyal audio yang terkandung dalam sinyal radio[6].

$$
\operatorname{Gain}_{d B m}=10 \log _{10}(\mathrm{~N})
$$

Setiap data FFT dilakukan konversi menjadi nilai $\mathrm{dBm}$, jumlah data spektrum $(\mathrm{dBm})$ harus sama dengan data FFT. Oleh karena itu dilakukan increment data spektrum ke N sampai semua data FFT berubah dalam satuan $\mathrm{dBm}$. Selanjutnya nilai $\mathrm{dBm}$ didapat diplot ke dalam bentuk spektrum, sehingga diketahui level dari frekuensi.

\subsection{Implementasi Sistem}

Implementasi sistem keseluruhan meliputi perakitan dan konfigurasi alat yang dipakai agar dapat mewujudkan sebuah spectrum analyzer. Gambar 6 menunjukkan implementasi keseluruhan perangkat keras setelah dirakit. Setelah semua perangkat dapat bekerja, langkah berikutnya adalah membuat program yang memiliki unjuk kerja spectrum analyzer menggunakan bahasa python.

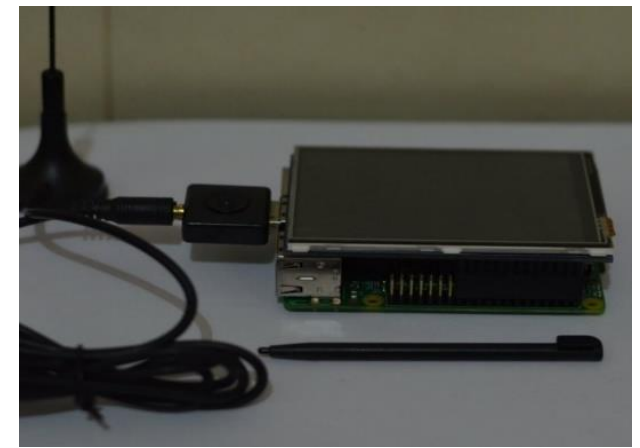

Gambar 6 Implementasi Keseluruhan Sistem

Gambar 7 menunjukkan implementasi program spectrum analyzer yang telah dibangun. Tampilan utama antarmuka program yang dibangun menampilkan spekrum frekuensi dengan tambahan 3 tombol menu. Tombol mode berfungsi untuk mengubah tampilan spektrogram menjadi waterfall spectrum. Tombol pengaturan digunakan untuk mengubah nilai frekuensi 
tengah, sample rate, gain dan nilai maksimum minimum spektrum. Kemudian tombol keluar digunakan untuk keluar dari program

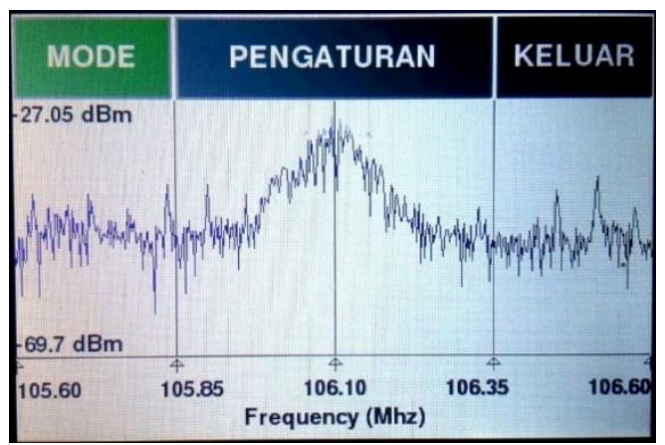

Gambar 7 Tampilan Antarmuka Halaman Utama

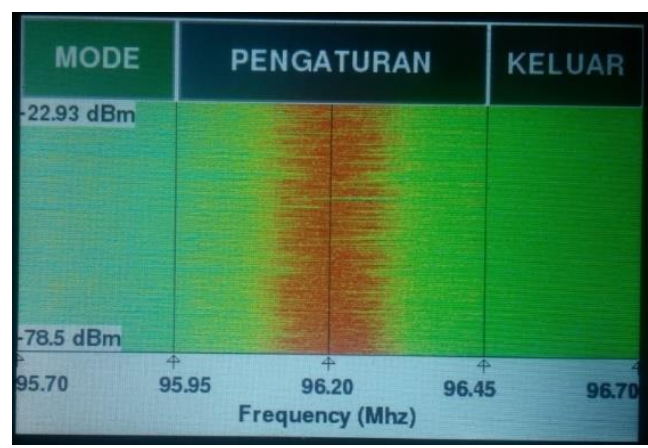

Gambar 8 Tampilan Antarmuka Waterfall Spectrum

Gambar 8 menunjukkan tampilan antarmuka waterfall spectrum. Tampilan waterfall spectrum menunjukkan bahwa adanya sinyal carrier pada frekuensi tertentu. Sinyal carrier adalah sinyal yang mempunyai level spektrum lebih tinggi dibanding level spektrum pada sinyal informasi. Warna oranye pada tampilan waterfall spectrum menunjukkan adanya sinyal carrier tersebut. Sedangkan warna hijau menunjukkan frekuensi sinyal informasi.

\section{HASIL DAN PEMBAHASAN}

\subsection{Pengujian Pengaruh Jumlah Cuplikan}

Pengujian ini dilakukan dengan memasukan jumlah cuplikan $(\mathrm{N})$ yang bervariasi. Mulai dari $\mathrm{N}=512$ sampai $\mathrm{N}=4.194 .304$. Jumlah cuplikan ini mempengaruhi penggunaan CPU dan memori dari Raspberry. Untuk mengetahui persentase penggunaan CPU pada Raspberry digunakan perintah \#top pada sistem operasi raspbian. Gambar 9 adalah informasi penggunaan CPU pada Raspberry saat menjalankan komputasi FFT dengan 4194304 titik.

\begin{tabular}{|c|c|c|c|c|c|c|c|c|}
\hline PI D UEER & PR & $\mathbf{N}$ & VI RT & RES & SHR S & \%(PPU & \%QVEM & TI ME+ COMMAD \\
\hline 4456 root & 20 & 0 & 94592 & $67 m$ & $13 \mathrm{~m} R$ & 100.0 & 7.8 & 0:55.64 python \\
\hline $1878 \mathrm{xrdp}$ & 20 & 0 & 20608 & $10 \mathrm{~m}^{2}$ & $2184 \mathrm{~S}$ & 3.3 & 1.2 & $3: 54.86$ xrdp \\
\hline $2445 \mathrm{pi}$ & 20 & 0 & 47956 & $25 \mathrm{~m}$ & $18 \mathrm{~m} \mathrm{~S}$ & 3.3 & 2.9 & 2:10.98 1xtermi nal \\
\hline $2343 \mathrm{pi}$ & 20 & 0 & 60932 & $22 \mathrm{~m}$ & $10 \mathrm{~m} \mathrm{~S}$ & 2.6 & 2.6 & 2:14.31 Xine \\
\hline
\end{tabular}

Gambar 9 Informasi Penggunaan CPU pada Raspberry Pi

Gambar 9 berisi informasi dari pengunaan prosesor dan memori (RAM) yang terpakai. Selain itu juga ada informasi mengenai waktu program berjalan, status program, memori fisik yang dipakai dan id program. Lebih jelas mengenai penggunaam CPU dan memori yang digunakan untuk menjalankan program dapat dilihat pada Tabel 1. 
Tabel 1 Penggunaan CPU dan Memori untuk Setiap N titik

\begin{tabular}{|c|l|c|c|c|c|c|}
\hline \multirow{2}{*}{ No } & \multirow{2}{*}{$\mathbf{N}$} & \multirow{2}{*}{$\mathbf{L o g}_{2} \mathbf{N}$} & \multicolumn{2}{|c|}{ FFT } & \multicolumn{2}{c|}{ Penggunaan } \\
\cline { 4 - 7 } & & & Perkalian & Penjumlahan & CPU (\%) & Memori (\%) \\
\hline 1 & 512 & 9 & 2.304 & 4.608 & 22,5 & 2,7 \\
\hline 2 & 1.024 & 10 & 5.120 & 10.240 & 24,6 & 2,7 \\
\hline 3 & 2.048 & 11 & 11.264 & 22.528 & 28,7 & 2,7 \\
\hline 4 & 4.096 & 12 & 24.576 & 49.152 & 31,8 & 2,7 \\
\hline 5 & 8.192 & 13 & 53.248 & 106.496 & 32,5 & 2,8 \\
\hline 6 & 16.384 & 14 & 114.688 & 229.376 & 43,8 & 2,8 \\
\hline 7 & 32.768 & 15 & 245.760 & 491.520 & 78,3 & 2,8 \\
\hline 8 & 65.536 & 16 & 524.288 & 1.048 .576 & 90,5 & 2,9 \\
\hline 9 & 131.072 & 17 & 1.114 .112 & 2.228 .224 & 91,8 & 3,0 \\
\hline 10 & 262.144 & 18 & 2.359 .296 & 4.718 .592 & 94,5 & 3,4 \\
\hline 11 & 524.288 & 19 & 4.980 .736 & 9.961 .472 & 95,0 & 4,0 \\
\hline 12 & 1.048 .576 & 20 & 10.485 .760 & 20.971 .520 & 97,3 & 4,7 \\
\hline 13 & 2.097 .152 & 21 & 22.020 .096 & 44.040 .192 & 100 & 5,3 \\
\hline 14 & 4.194 .304 & 22 & 46.137 .344 & 92.274 .688 & 100 & 7,8 \\
\hline
\end{tabular}

Data pada Tabel 1 menunjukkan bahwa semakin besar nilai $\mathrm{N}$ maka akan semakin membebani kerja CPU. Hal ini disebabkan karena semakin banyak nilai N maka akan semakin banyak pula perhitungan kompleks yang dilakukan CPU. Perhitungan kompleks dari FFT menggunakan persamaan (N/2) $\log _{2} \mathrm{~N}$ untuk setiap perkalian dan $\operatorname{NLog}_{2} \mathrm{~N}$ untuk penjumlahan kompleks[7]. Selain CPU, besarnya $\mathrm{N}$ juga mempengaruhi penggunaan memori sementara (RAM). Hal ini terjadi karena semakin banyak nilai $\mathrm{N}$ maka ruang penyimpanan yang harus disediakan juga semakin besar. Perubahan persentase dari CPU dan memori terhadap $\mathrm{N}$ ditunjukan pada Gambar 10
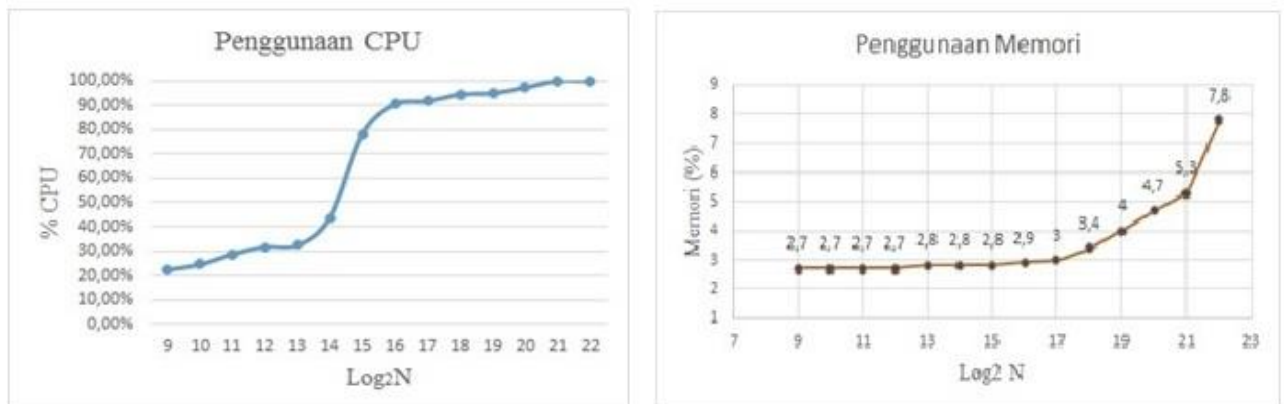

Gambar 10 Grafik Penggunaan CPU dan Memori Terhadap Jumlah Cuplikan

Gambar 10 menunjukkan bahwa kenaikan penggunaan CPU terjadi sangat besar ketika diberikan $\mathrm{N}=32.768$ titik yaitu sebesar 78,3\%. Hal tersebut membuktikan bahwa kinerja CPU mulai terbebani dengan komputasi FFT yang menghasilkan 245.760 perkalian dan 491.520 penjumlahan kompleks. Lebih dari 32.768 titik nilai perkalian dan penjumlahan kompleks semakin besar, sehingga menyebabkan beban CPU mencapai lebih dari 90\%. Setelah dilakukan pengujian pada aplikasi, beban CPU yang mencapai $90 \%$ membuat aplikasi berjalan lambat dan beberapa fungsi menjadi error. Oleh sebab itu penggunaan $\mathrm{N}$ antara 65.536 titik sampai 4.194.304 titik yang diimplementasikan pada Raspberry lebih baik dihindari.

Selain CPU, besarnya jumlah cuplikan $(\mathrm{N})$ juga mempengaruhi penggunaan memori (RAM). Gambar 10 menunjukkan bahwa semakin besar nilai $\mathrm{N}$ maka penggunaan memori yang digunakan juga akan semakin besar. Hal ini terjadi karena adanya ruang memori yang digunakan untuk menyimpan hasil dari perhitungan FFT. Semakin banyak N maka komputasi yang dilakukan semakin banyak dan ruang penyimpanan yang harus disediakan juga semakin besar. 


\subsection{Pengujian Jangkauan Maksimal dan Minimal Frekuensi}

Pengujian pengukuran jangkauan minimal dan maksimal frekuensi dilakukan dengan mengganti-ganti nilai frekuensi tengah pada program yang dibangun. Jangkauan frekuensi dari program tergantung pada kemampuan dari tuner yang dipakai. Pada sistem digunakan tuner tipe Rafael Micro R820T dengan jangkauan $24 \mathrm{MHz}$ sampai $1.766 \mathrm{MHz}$ [8]. Namun setelah dilakukan pengukuran, didapatkan hasil bahwa nilai maksimal frekuensi adalah $1.769 \mathrm{MHz}$. Apabila diberikan nilai frekuensi melebihi $1.769 \mathrm{MHz}$, maka sistem akan berhenti bekerja. Gambar 11 menunjukkan pesan error yang terjadi pada saat diberikan nilai frekuensi 1.770 MHz.

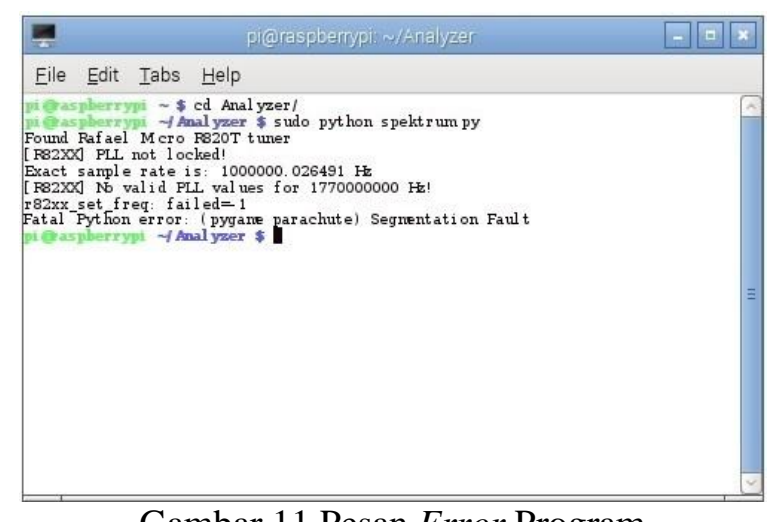

Gambar 11 Pesan Error Program

Sedangkan untuk batas jangkauan minimal frekuensi dari sistem adalah $24 \mathrm{MHz}$. Hal ini berdasarkan hasil pengukuran, apabila diberikan nilai frekuensi kurang dari $24 \mathrm{MHz}$ maka program tidak dapat menampilkan adanya sinyal radio. Gambar 12 menunjukkan tampilan waterfall spectrum pada frekuensi tengah $23 \mathrm{MHz}$ dengan sample rate $2 \mathrm{MHz}$.

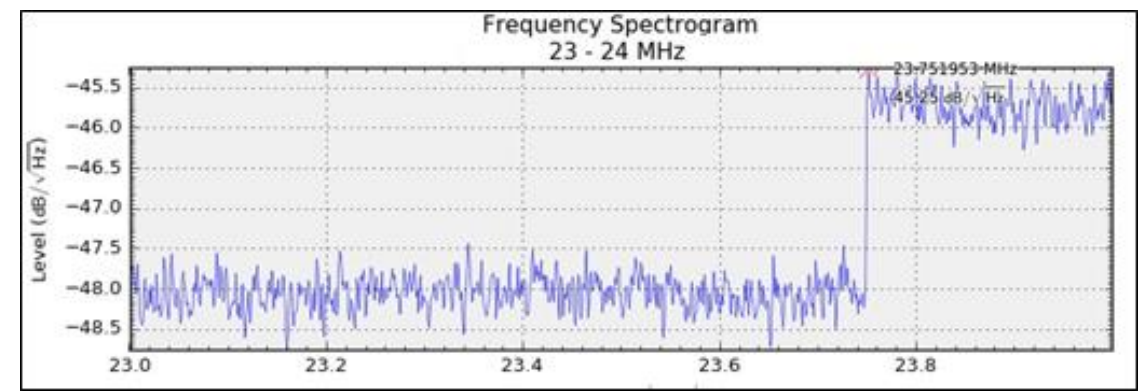

Gambar 12 Tampilan Visualisasi Spektrum Nilai Minimal Frekuensi

Gambar 12 menunjukkan tampilan hasil visualisasi spektrum pada frekuensi 23 sampai $24 \mathrm{MHz}$. Pada frekuensi 23,75 MHz level spektrum menurun jauh karena tuner tidak dapat melakukan scanning frekuensi dibawah $24 \mathrm{MHz}$. Sehingga penggunaan minimal frekuensi yang dianjurkan adalah $24 \mathrm{MHz}$ atau lebih.

\subsection{Pengujian Sinyal RF Pada Alat Komunikasi Radio}

Salah satu fungsi dari spectrum analyzer adalah untuk menguji alat komunikasi radio baik pengujian saat produksi, perawatan maupun jika terjadi kerusakan[9]. Oleh karena itu untuk menguji kemampuan purwarupa spectrum analyzer yang telah dibuat, perlu adanya proses pengujian untuk menampilkan spektrum dari sinyal RF. Keluaran sinyal RF diperoleh dari alat komunikasi radio. Tabel 2 adalah hasil pengujian pengukuran sinyal RF menggunakan beberapa alat komunikasi radio. Terdapat 3 alat yang digunakan dalam pengujian ini yaitu Handy Talky (HT), remote car dan remote control. 
Tabel 2 Pengujian Daya Pancar Sinyal RF

\begin{tabular}{|c|l|c|c|}
\hline \multirow{2}{*}{ No. } & \multicolumn{2}{|c|}{ Alat } & \multicolumn{2}{|c|}{ Pengukuran } \\
\cline { 3 - 4 } & & Frekuensi & Level \\
\hline 1. & HT Olinca TH-888A & $142,1 \mathrm{MHz}$ & $-26,74 \mathrm{dBm}$ \\
\hline 2. & HT Baofeng UV5R & $520 \mathrm{MHz}$ & $-26,78 \mathrm{dBm}$ \\
\hline 3. & Remote Car & $433,94 \mathrm{MHz}$ & $-22,63 \mathrm{dBm}$ \\
\hline 4. & Remote Control & $27.15 \mathrm{MHz}$ & $-22,83 \mathrm{dBm}$ \\
\hline
\end{tabular}

Hasil pengujian Tabel 2 membuktikan bahwa purwarupa yang dibangun mampu menunjukkan nilai frekuensi dan level dari sinyal yang dipancarkan oleh alat komunikasi radio. Purwarupa yang dibangun dapat menampilkan level spektrum dari frekuensi VHF sampai UHF. Saat pengujian daya pancar, alat pengujian harus diletakan pada jarak yang dapat dideteksi oleh purwarupa spectrum analyzer.

\subsection{Pengujian Perbandingan Pengukuran Spectrum Analyzer}

Pengujian ini dilakukan dengan cara membandingkan hasil spektrum dari sistem yang dibangun dengan spectrum analyzer pabrikan. Tujuan dari pengukuran adalah untuk mengetahui tingkat sensitifitas sistem terhadap sinyal radio yang dipancarkan oleh stasiun pemancar. Tipe spectrum analyzer yang dipakai untuk membandingkan adalah Anritsu MS2720T. Contoh perbandingan pengukuran spektrum dari Anritsu MS2720T dengan sistem ditunjukkan pada Gambar 13.

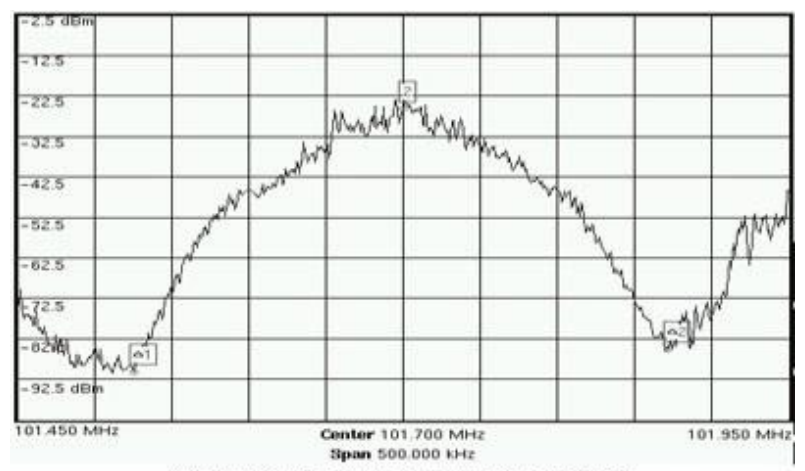

(a) Tampilan Spektrum Pada Anritsu MS2720T

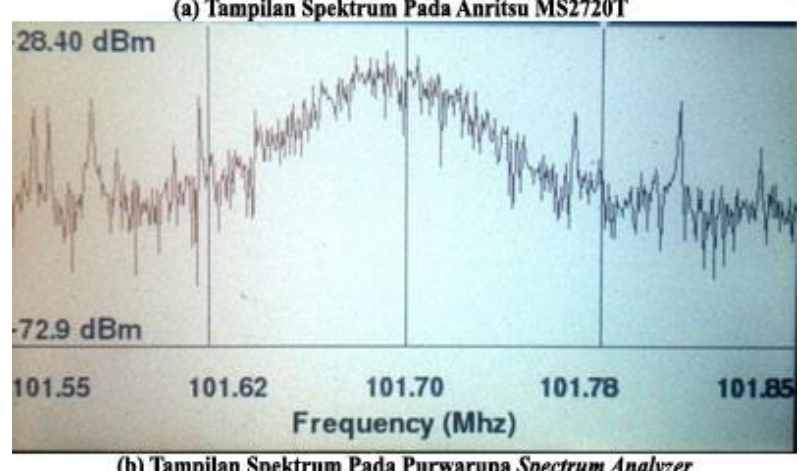

(b) Tampilan Spektrum Pada Purwarupa Spectrum Analyzer

Gambar 13 Perbandingan Power Spektrum

Gambar 13 menampilkan visualisasi spektrum dari stasiun radio swaragama FM (101,7 MHz). Pada Anritsu MS2720T power spektrum dari frekuensi 101,7 adalah -25,66 dBm, sedangkan pada purwarupa tercatat $-28,40 \mathrm{dBm}$. Kemudian dilakukan pengukuran terhadap sinyal radio FM lain yaitu pada jangkauan 88 sampai $107 \mathrm{MHz}[10]$. Hasil perbandingan 
pengukuran spektrum antara Anritsu MS2720T dengan purwarupa ditunjukkan pada Gambar 14.

Terdapat perbedaan power spektrum diantara keduanya. Pada MS2720T memiliki nilai power yang besar dibanding purwarupa. Hal ini terjadi akibat antena penerima yang dipakai oleh Anritsu MS2720T berada pada tower dengan ketinggian 10 meter sehingga mampu menerima sinyal lebih kuat. Namun meskipun memiliki power spektrum yang berbeda-beda, frekuensi sinyal radio yang ditunjukkan kedua alat adalah sama.

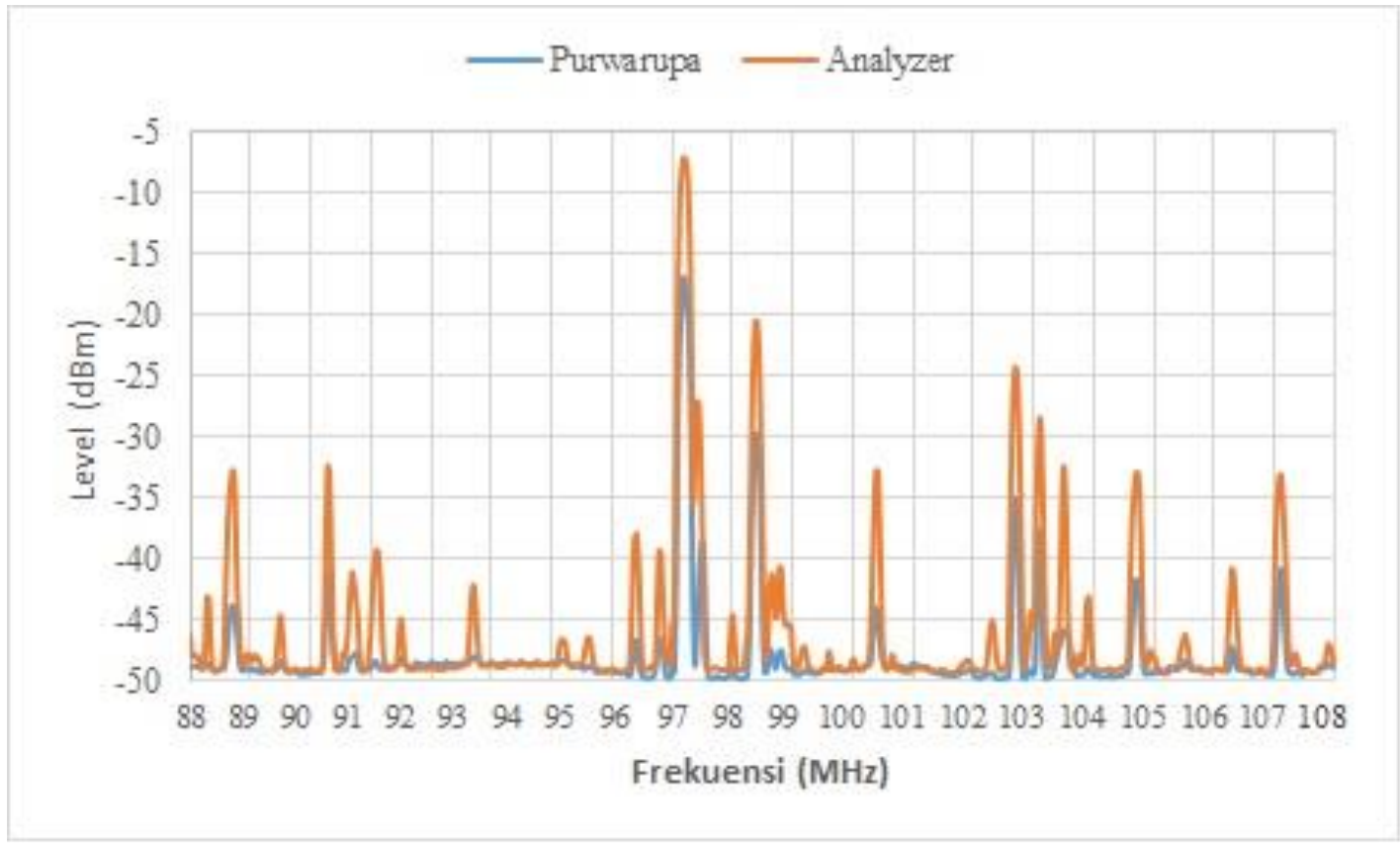

Gambar 14 Perbandingan Pengukuran Spektrum dengan Anritsu MS2720T

Selain ketinggian antena, perbedaan power spektrum pada Gambar 14 juga sebabkan oleh perbedaan jenis antena. Pada purwarupa menggunakan antena omni yang menangkap sinyal dari berbagai arah $\left(360^{\circ}\right)$, sedangkan pada Anritsu MS2720T digunakan antena grid yang dapat menangkap sinyal sesuai antena diarahkan $\left(180^{\circ}\right)$. Sehingga ada beberapa nilai power spectrum pada Anritsu MS2720T yang lebih besar dibandingkan pada purwarupa karena antena grid tepat mengarah pada stasiun pemancar.

\section{KESIMPULAN}

Berdasarkan dari hasil penelitian dan pembahasan yang dilakukan maka diperoleh kesimpulan sebagai berikut:

1. Purwarupa spectrum analyzer yang dibangun mampu menampilkan spektrum frekuensi sinyal radio dengan lancar pada jumlah cuplikan dari 512 sampai 32.768 titik. Sebab penggunaan jumlah cuplikan lebih dari 32.768 titik akan membebani cpu dan memori dari SBC, sehingga menyebabkan sistem menjadi lambat.

2. Hasil dari pengujian menunjukkan bahwa jangkauan minimal frekuensi dari sistem adalah $24 \mathrm{MHz}$, sedangkan jangkaun maksimal frekuensi adalah $1.769 \mathrm{MHz}$.

3. Hasil perbandingan pengukuran menggunakan spectrum analyzer Anritsu MS2720T menunjukkan bahwa sistem dapat menunjukkan letak spektrum frekuensi radio FM secara tepat. 


\section{SARAN}

Untuk pengembangan penelitian lebih lanjut, diberikan saran sebagai berikut:

1. Purwarupa spectrum analyzer berbasis SDR masih dalam bentuk skala laboraturium dan diuji coba dengan daerah frekuensi dengan orde $\mathrm{MHz}$, sehingga perlu dikembangkan lebih lanjut dan diteliti untuk jangkauan frekuensi yang lebih tinggi (orde $\mathrm{GHz}$ ).

2. Perlu adanya peningkatan spesifikasi RTL-SDR yang digunakan. Pada penelitian ini menggunakan chip R820T, mungkin dapat diganti menggunakan chip yang spesifikasinya lebih tinggi seperti E4000 atau R820T2.

3. Perlu dilakukan penelitian lanjutan untuk menambah fasilitas yang ada pada purwarupa spectrum analyzer. Misalnya fasilitas untuk mengatur resolution bandwith (RBW), penambahan maker untuk mengetahui level dari beberapa sinyal radio dll.

\section{UCAPAN TERIMA KASIH}

Penulis mengucapkan terima kasih kepada semua pihak yang telah memberi dukungan baik secara moril maupun materiil terhadap penelitian ini.

\section{DAFTAR PUSTAKA}

[1] Rentanu, I. W., 2012, Audio Spectrum Analyzer Menggunakan Mikrokontroler Atmega32, Tugas Akhir, Jurusan Pendidikan Teknik Elektronika, Univ. Negeri Yogyakarta, Yogyakarta.

[2] Yogiswara, P. A., Pranowo, F. X. H., Budiman, L. H., 2010, Perancangan dan Implementasi Sistem Perangkat Lunak Client Server Untuk Alat Ukur Spectrum Analyzer, Skripsi, Jurusan Ilmu Komputer, Univ. Bina Nusantaara, Jakarta.

[3] Cooley, J.W., dan Tukey, J.W., 2000, An Algoritm for The Machine Calculation of Complex Fourier Series. Mathematics Of Computation Journal, Vol 1, hal 297-301.

[4] Sierra, E, G., 2015, Low Cost SDR Spectrum Analyzer and Analog Radio Receiver Using GNU Radio, Raspberry Pi 2 and SDR-RTL Dongle, Proceeding of 7th IEEE LatinAmerican Conference on Communication, Arequipa, 4 - 6 Nov.

[5] Quraeshi, F., 2009, Analysis of Twiddle Factor Memory Complexity of Radix 2 Pipelined FFTs, Proceeding Conference Record of The Forty-Third Asilomar Conference on Signal Systems and Computers, California, 1 - 4 Nov.

[6] Cerna, M., Harvey, A.F., 2000, The Fundamentals of FFT-Based Signal Analysis and Measurement in LabView dan LabWindows, http://www.ni.com/white-paper/4278/en/, diakses tg1 7 Juni 2016.

[7] Lyons, R. G., 2001, Understanding Digital Signal Processing, Prentice Hall International, New Jersey

[8] Laufer, C., 2014, The Hobbyist's Guide to the RTL-SDR : Really Cheap Software Defined Radio, http://www.qsl.net/docs/TheHobbyistguideToRTL-SDR.pdf, diakses tgl 15 Februari 2016. 
[9] Marpanaji, E., 2012, Aplikasi Platform Komputasi Software-Define Radio (SDR) untuk Digital Spectrum Analyzer, Prosiding Pertemuan Ilmiah XXV HFI Jateng \& DIY, Purwokerta, 9 April.

[10] Hioki, W., 1998, Telecommunications, third edition, Prentice Hall International, New Jersey. 